Jurnal Pena Sains Vol. 5, No. 2, Oktober 2018

p-ISSN: 2407-2311

e-ISSN: 2527-7634

\title{
STUDENTS MISCONCEPTION: THE DEVELOPING OF SOCRATIC DIALOGUE MEDIA ON TEMPERATURE AND HEAT
}

\author{
Sujito $^{1 *}$, Irvany Nurita Pebriana ${ }^{2}$, Hestiningtyas Yuli Pratiwi. ${ }^{3}$, Abdul Hayyi ${ }^{4}$, Kadim $^{2}$ \\ Masjkur $^{5}$, Asim ${ }^{6}$, Sutopo ${ }^{7}$ \\ 1,2,5,6,7 Jurusan Fisika Fakultas Matematika Dan ilmu Pengetahuan Alam Universitas Negeri Malang \\ Malang 65145, Indonesia \\ *sujito.fmipa@um.ac.id \\ ${ }^{3}$ Prodi Pendidikan Fisika Fakultas Sainteks Universitas Kanjuruhan Malang \\ Malang 65148, Indonesia \\ hestiphysics@gmail.com \\ ${ }^{4}$ SMK Negeri 6 Jember Jawa Timur \\ Jember 68155, Indonesia \\ abdulhayyi78@yahoo.co.id
}

Accepted: August 27, 2018

Published: October 31, 2018

\begin{abstract}
This purpose of this study is to improve media of Socratic dialogue that has been developed by the previous researcher and to determine the effect of the Socratic dialogue in enhance understanding of heat concept. As a result of prior research, showed students still have a misconception. Data collected from one institution of high school in Malang City using pre and posttest. Student's conceptual changes that occur previous, during, after will be analyzed based on pretest and posttest scores and rethinking sequence of used record Socratic dialogue media. To explore more in-depth, the researcher conducted interviews with students on this concept. This result showed Socratic dialogue media could help students be aware mistakes or students become convinced if their opinion is correct. This study is important because it uses to improve student's comprehension to move from the false toward the right concept. In some cases, the result of this study used for recovery and prevent to misconception. It can solve with appear cognitive conflict in the minds of students through Socratic dialogue.
\end{abstract}

Keywords: Socratics dialogue media; misconceptions; heat 


\section{Introduction}

Several studies reveal there are misconceptions related to the concept of heat. First, the misconception that heat is understood as a substance, possessed by high-temperature objects, which flows due to temperature differences (Alwan, 2011; Başer, 2006; Brookes \& Etkina, 2015; Marcisz \& Woien, 2010). Misconception is common because before knowing heat is one form of energy, in the $18^{\text {th }}$ century scientists considered heat to be a type of flow (called caloric) contained in every object and not visible to the human eye (Sunardi, Retno P., \& Andreas B., 2016). Misconception at the same time indicates the assumption that heat is something that is stored or possessed by objects. Second, the results of the preliminary research indicate that there is an assumption that heat moves from an object that has high internal energy to an object that has low internal energy. This assumption is not entirely wrong, but it is prone to cause misconceptions.

The misunderstanding can be caused by the inequality of meaning between physics and in everyday life. For example, in everyday life heat is interpreted as energy contained in food, whereas in physics, it is interpreted as energy that moves as a result of temperature differences. (Sunardi et al., 2016). Another example is the word "heat capacity" in various literatures can provide false and misleading understanding, because it states that "a lot of heat has an object". Misconception can produce an assumption that temperature is a measure of the amount of heat that an object (Alwan, 2011).

$\mathrm{T}$ In other hand, heat is an abstract and unobserved concept so the idea of heat is self-developed through everyday life (Başer, 2006). Conception errors about heat are also caused by the fact that heat is related to other concepts where the relationship often causes students to confuse heat with other quantities. For example, heat is defined as energy that is moving from one object/place to another due to temperature differences.

This definition connects heat with two other concepts namely energy and temperature. The concept of energy is a very abstract concept that is difficult to define in one or two sentences (Raymond A. Serway \& Jewet Jr., 2014). It is very abstract, that scientists cannot define it explicitly and apply generally but only in specific contexts (Sutopo \& Waldrip, 2014). Temperature microscopically as a representation of the average kinetic energy of each constituent particle, so that not a few students experience confusion to distinguish heat from internal energy and its relation to temperature (Leinonen, Asikainen, \& Hirvonen, 2013). Heat is indeed energy, but not like kinetic energy or potential energy that can be possessed or stored by objects (Brookes \& Etkina, 2015).

Physics textbooks also contribute and even strengthen the existence of misconceptions. Occurrence misconceptions due to textbooks are often caused by students' errors in interpreting the meaning of the metaphor in the textbook (Brookes \& Etkina, 2015). For example, the expression "heat flows..." gives the impression that heat is a fluid like heat in a caloric theory. It is thus important to define the concept precisely in order not to disturb the students' learning process.

Misconception is believed to inhibit the process of accepting new concepts (Alwan, 2011). Therefore many physics education researchers are interested in overcoming heat misconceptions. In principle, these efforts are to make students aware that they experience 


\section{The Students Misconception: The Developing of Socratic Dialogue Media}

misconceptions then guide students to turn their conceptions into scientific concepts through several activities.

The concept of learning physics is very basic. Erroneous concepts that have occurred to students will interfere with the effectiveness of learning and disrupt the thinking of students in receiving the next knowledge. Basically students entering the class are full of preconceptions about what the teacher will teach. The teacher is unaware of the preconception and the student himself does not realize it. This implies that before the teacher teaches a new concept, the teacher must know that in the brain of the student there is a concept even though in fact it is different.

Some alternatives have been done by previous researchers to reduce misconceptions and improve students' understanding of heat. For example, applying Conceptual Change Oriented Instruction (Başer, 2006), and using discovery learning with cognitive conflict strategies (Kang, Scharmann, Kang, \& Noh, 2010). In both these studies, students are given questions that gave rise to the conflict in the minds of students, and then they had a discussion and question-answer that leads to a shift towards true conception. Learning outcomes can improve understanding of material concepts of temperature and heat. But the implementation of the cognitive conflict strategy is still a problem. In learning, it is difficult to know whether there is cognitive conflict or not in the students mind.

In addition, inquiry learning is the start of learning by presenting the phenomenon and raise issues relating to the material of heat that will be resolved through experiments in groups to collect data, discuss, and make inferences, then presented to friends of the class to be responded to by other pupils and teachers (Pebriana, 2016). At the end of the activity, students apply the concepts they have obtained in the practice questions given by the teacher.

The results show a decrease in the number of students who experience misconceptions including (1) heat equal to temperature, (2) heat can increase the temperature or change the form of matter only. Nevertheless, there are still unchanging misconceptions before and after learning, namely heat is a particle that can be stored in an object or moves from one object to another.

Based on these findings, it can be concluded that learning that facilitates students to construct or find or correct concepts requires a long time, so there needs to be additional time outside the classroom to discuss the matter. In addition, students also need to be given additional questions about the concept to improve understanding of the concept while overcoming student misconceptions (Prince, Vigeant, \& Nottis, 2012).

One form of conceptual questioning that has the potential to trigger changes in conception is the Socratic question, namely questions that pursue, deep, and focus on essential concepts, principles, issues, or problems that aim to test the truth, clarify, and elaborating on students' ideas (Antwi \& Aryeetey, 2015).

A series of Socratic questions submitted to students will make students aware if his opinion is wrong. $\mathrm{He} / \mathrm{she}$ would change it or if the concept that he/she understands is correct, it will be more confident in the concept. Socratic questions can; 1) improve the basis of the most basic things; (2) investigate more deeply; (3) find the structure of one's mind; (4) help someone develop sensitivity to clarifying the data obtained ; (5) consider everything through their own reasoning; (6) and able to analyze claims proof of the truth, make inferences, issues that developed, assumptions used, the 


\section{Sujito}

consequences of acquired reality, the concept of a concept, and a different opinion (Antwi \& Aryeetey, 2015).

Several studies have applied questions (dialogue) Socratic directly in group discussions and class discussions. Technically this is difficult to do, because Socratic dialogue is ideally given by teachers to students personally or at least in small groups of students (Oyler \& Romanelli, 2014).

Varma dkk (2016) have made a series of Socratic questions to help students understand the concepts of temperature and heat. Sokratik questions are packaged in the form of flash media as independent teaching materials that give students the opportunity to use them many times so that they can be seen changing the flow of students' thinking (Varma et al., 2016). However, the media of the Socratic questions are less effective in improving students' understanding (Boa, Wattanatorn, \& Tagong, 2018). The reason is that the Socratic question media do not immediately provide feedback or instant reinforcement, so that students cannot know their mistakes, consequently students do not realize that they have a right or wrong understanding.

This research is intended to correct the Media weaknesses of the Socrates Questions that have been developed by Rahmawati. In the methodology, pure Socratic dialogue developed from the thinking of researchers, not based on the real thoughts of the students. Though acceptance of a concept between one student and another student is not same (Başer, 2006). Therefore, it is necessary to have a dialogue with students and students to obtain the lines of thought that cover the understanding of students and students.

\section{Research Method}

This study aims to develop the Media Socratic Dialogue which is used to determine changes in the understanding of the concept of heat. Socratic Dialogue Media Development is synonymous with research and development of assessment instruments (Creswell, 2013). Therefore this study adapted the three stages used by Treagust (1988) in developing assessment. The three stages include the stage of determining the content, the stage of extracting conception and student reasoning, and the stage of developing the Socio-Dialogue Media (Creswell, 2013).

The flow of this research uses pretest and posttest as quantitative data. The pretest is given just before the respondent receives the Socio-Dialogue Media. After giving the pretest, respondents were given Media Socio Dialogue. The Socratic Dialogue Media is used to guide respondents construct or find or correct heat concepts that allow respondents to gain new knowledge so as to improve the understanding of the concept of heat. In addition, through the Media Socio Dialogue, respondents' reasoning flow can be identified in solving the main problems related to the heat concept presented. The results of the respondent's Socratic dialogue track record are used as qualitative data.

After completing the socratic dialogue, the respondent was given a posttest to find out the understanding of the concept of the respondent after using the Media Socratic Dialogue. The posttest problem is the same as the pretest. Based on the results of the pretest and posttest, it will be known the effect of using the Socratic Dialogue Media on students' conceptual understanding of heat. This can be known through $d$-effect size, and $N$-gain. These results were then analyzed and related to the respondents' flow of 


\section{The Students Misconception: The Developing of Socratic Dialogue Media}

thought obtained from the results of the track record of the use of the Media Socratic Dialogue.

\section{Results and Discussion}

\section{Product Description}

The Socratic Dialogue Media contains dialogue using questions that clarify and test respondents' beliefs about their understanding of heat concepts and other related concepts. The Socratic Dialogue Media used as self-learning material that is packaged in the form of web media. The Socratic Dialogue Media can be used to see the flow of thought used by respondents. The flow shows how the respondent's understanding in completing the main topic is heat. This main problem measures respondents' understanding regarding temperature, internal energy, heat, and heat propagation principles to explain heat propagation events. The main problems in the Socratic Dialogue Media are as follows.
$50 \mathrm{~g}$ of $80{ }^{\circ} \mathrm{C}$ hot water poured into a vessel containing $200 \mathrm{~g}$ of cold water at $25{ }^{\circ} \mathrm{C}$. Which statement is correct?

(a) cold water receives energy from hot water in the form of heat

(b) heat moves from hot water to cold water because hot water contains more heat

(c) heat moves from hot water to cold water because hot water has greater internal energy than cold water.

(the correct answer is (a)).

Each answer contains a series of Socratic dialogues. Based on the steps and grooves of the questions in the SocioDialogue Media, it is expected that respondents can have a good understanding of the heat concept. An example of a series of Socratic dialogues for answers (a) can be seen in Figure 1. An example of a series of Socratic dialogues for answers (b) can be seen in Figure 2. An example of a series of Socratic dialogues for answers (c) can be seen in Figure 3.

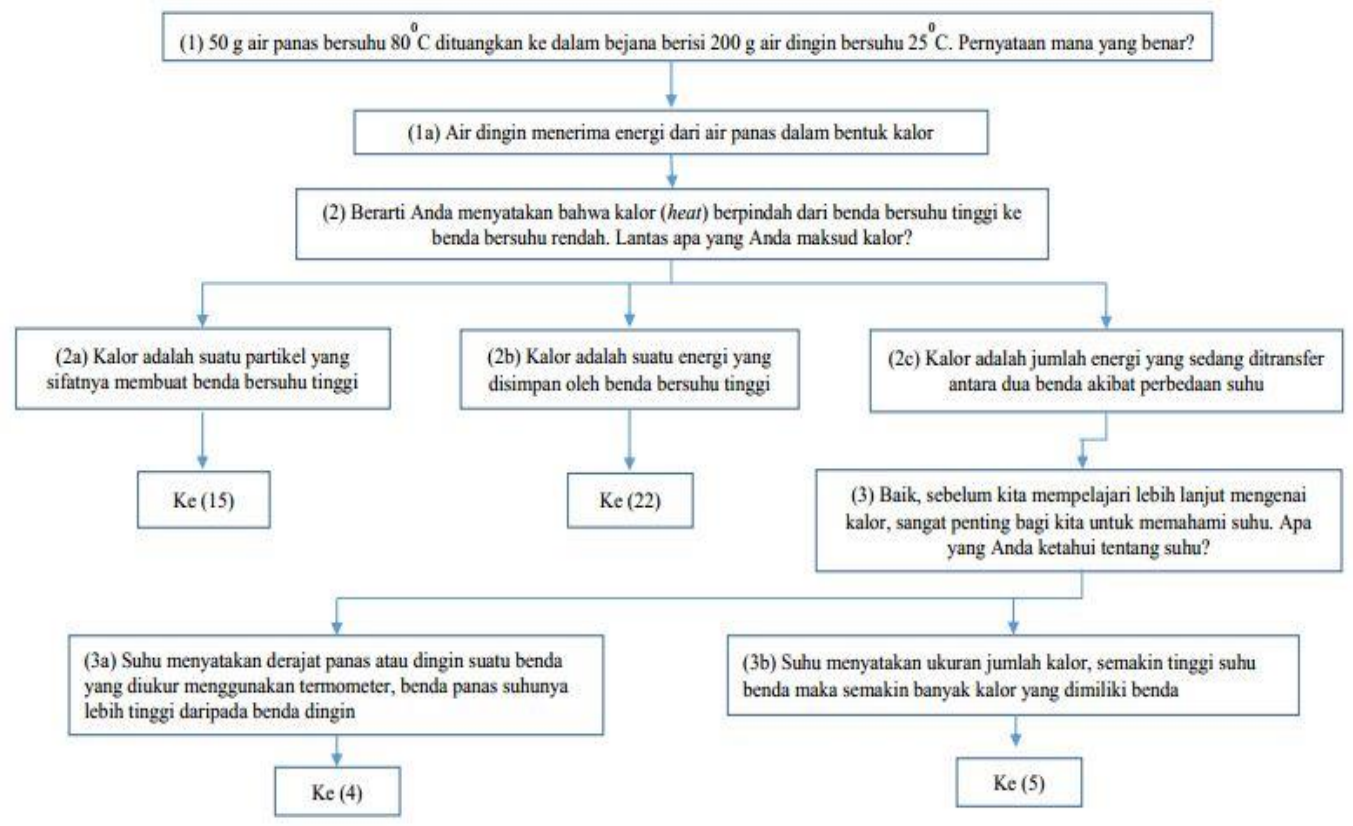

Figure 1. The example of the series of Socratic dialogues for answers (a). 


\section{Sujito}

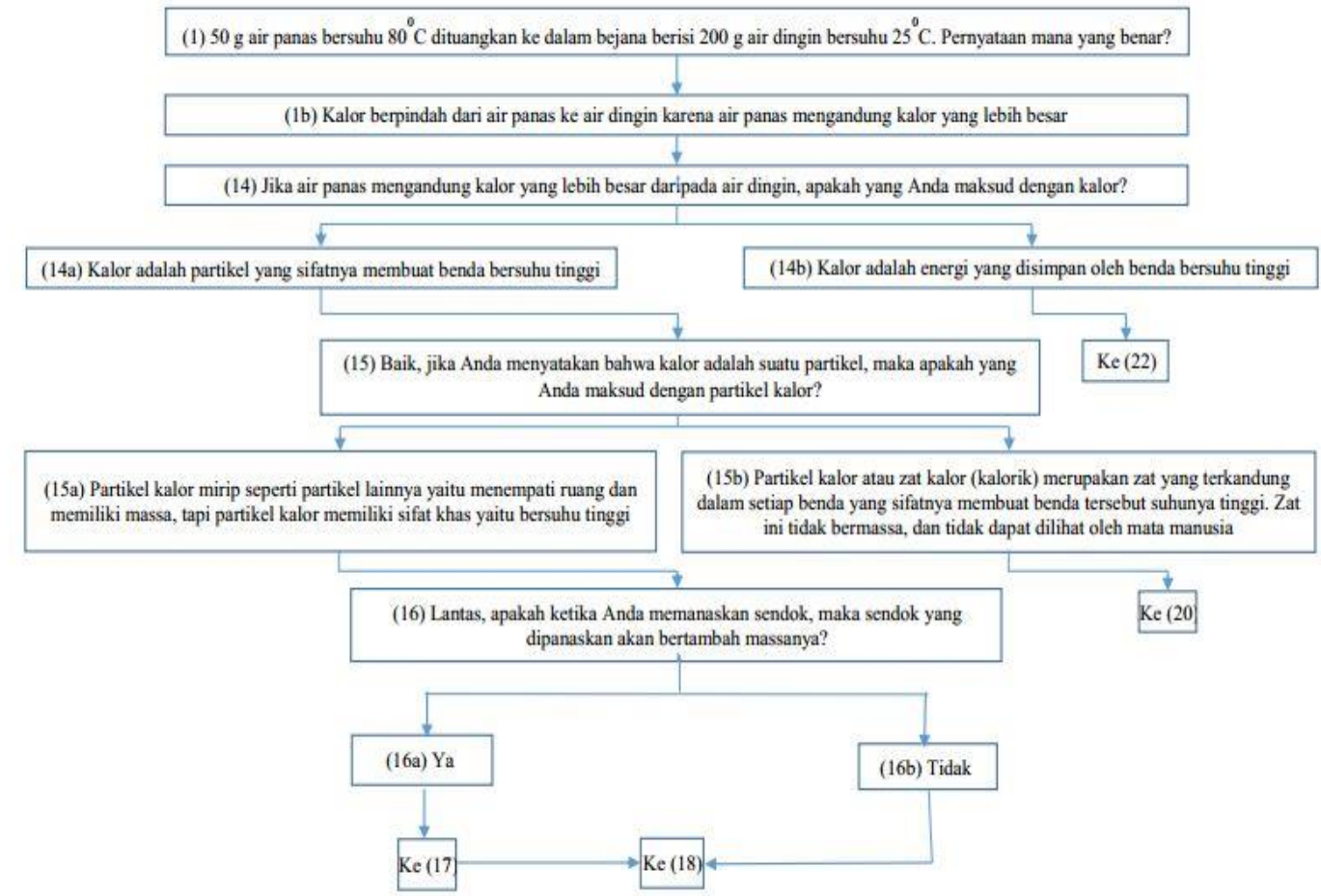

Figure 2. Example of a series of Socratic dialogues for answers (b).

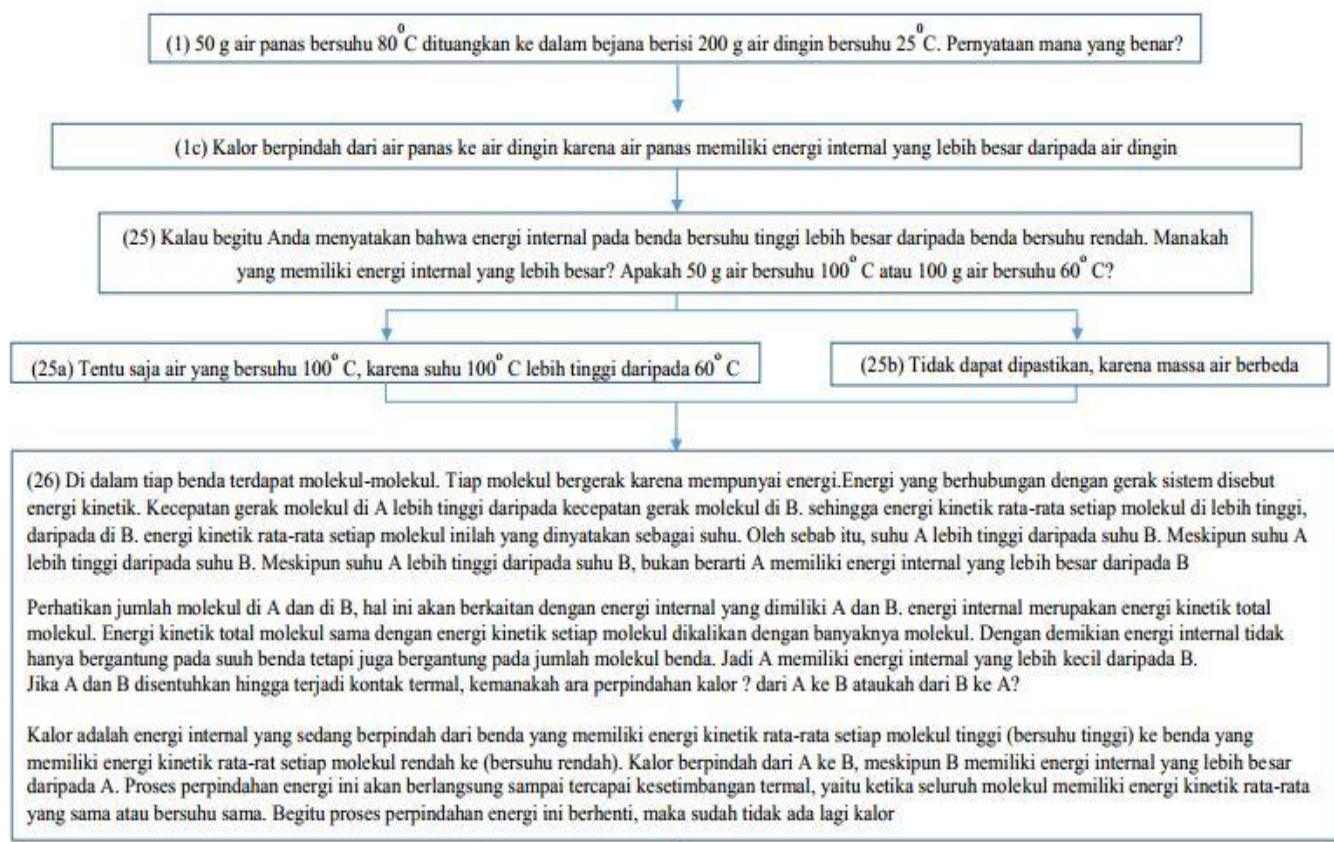

yang sama atau bersuhu sama. Begitu proses perpindahan energi ini berhenti, maka sudah tidak ada lagi kalor

$$
\mathrm{Ke}(27)
$$

Figure 3. Example of a series of Socratic dialogues for answers (c). 


\section{The Students Misconception: The Developing of Socratic Dialogue Media}

\section{Product Effectiveness}

Student understanding is analyzed quantitatively and qualitatively. Quantitative analysis is an analysis of changes in scores from pretest to posttest. Qualitative analysis is an analysis of the flow of thought of respondents in using the Socratic Dialogue Media. Quantitative analysis is used to see the effectiveness of the use of the Socratic Dialogue Media. Quantitative data on pretest and posttest are presented in Table 1.

Table 1. Descriptive Statistics Score Changes at Pretest and Posttest.

\begin{tabular}{lll} 
& Pretest & Posttest \\
\hline Mean & 2.6667 & 4.1333 \\
Median & 3.0000 & 4.0000 \\
Std. Deviation & 1.11270 & 0.83381 \\
Skewness & -0.306 & -0.274 \\
Minimum & 1.00 & 3.00 \\
Maximum & 4.00 & 5.00
\end{tabular}

Skewnes spretest and posttest score is -0306 and -0274 . Skewness values are between -1 and 1 indicating that data is normally distributed (Morgan et al., 2005:
31). These results indicate that the data is normally distributed, but because the number of respondents is less than 30 , the Wilcoxon test is conducted.

The Wilcoxon test results obtained a value of $Z-3,025$ with a significance of 0.002 . Because the significance of less than 0.05 can be concluded that the average posttest is greater than the pretest average significantly. In other words , there is a significant difference between the pretest score and the posttest score . A significant difference is that Media Political Dialogue can improve understanding of concepts related to heat.

The strength of increasing scores from pretest to posttest was measured using $d$-effect size and $N$-gain . Based on the calculation, the value of $d$-effect size is 1.62 which is included in the very high criteria. Calculation of $\mathrm{N}$-gain produces a value of 0.67 which is included in the criteria for the upper medium. The following is a diagram of the number of respondents who answered correctly at the pretest and posttest of the total respondents as many as 13 people.

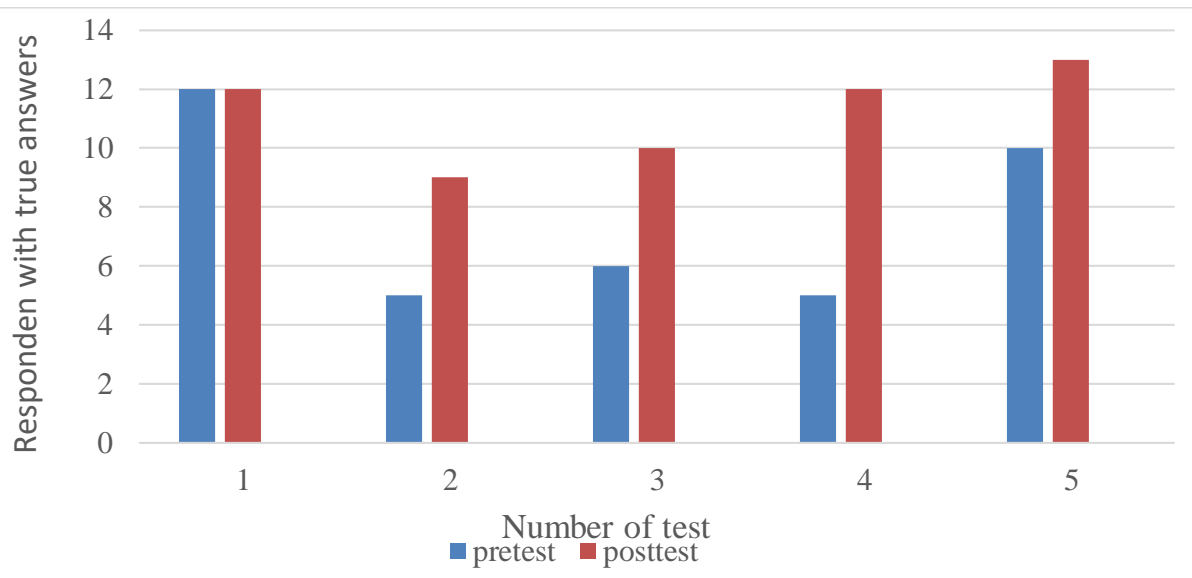

Figure4. Diagram of the number of respondents who answered correctly at the pretest and posttest

Figure 4 shows the number of respondents who answered correctly at the pretest and posttest, with the number of respondents who answered correctly as ordinate and the question number as abscissa. Overall, the number of respondents who answered correctly 


\section{Sujito}

increased from the pretest to the posttest, except in number 1 the number of respondents who answered correctly was 12 respondents. These results indicate that The Socratic Dialogue media can improve the understanding of respondents' concepts regarding heat.

\section{Conclusion}

The Socratic Dialogue Media resulting from contains dialogue using questions that clarify and test respondents' beliefs about their understanding of heat concepts and other related concepts, which are packaged in the form of web media to be used as self-learning material. The Socratic Dialogue Media also presents reinforcement of material in the form of videos so that media users are not tired or tired of reading, while making it easier to understand. The Socratic Dialogue Media also provides "save" and "print" facilities for storing and printing flow transcripts that have been passed by the user, so that users can re-read the dialog that has been done.

The Socratic Dialogue Media can significantly improve the understanding of heat concepts and other related concepts $(\mathrm{sig}=0.000)$ with a $d$-effect size of 1.62 (very high) and $N$-gain of 0.67 (upper medium). The results of this study can be used as one of the alternative selflearning materials for students who can help construct concepts while overcoming misconceptions and deepen understanding of the concept of high school students about heat.

To complete the whole series of Socratic dialogues requires concentration and a long time, allowing respondents to be tired when completing the Socratic dialogue. Thus, for further research, it is hoped that the "pause" facility at the Media Socio Dialogue should be given to provide the opportunity for respondents to rest.

\section{References}

Alwan, A. A. (2011). Misconception of heat and temperature Among physics students. Procedia - Social and Behavioral Sciences, 12, 600614.

https://doi.org/10.1016/j.sbspro.201 1.02 .074

Antwi, V., \& Aryeetey, C. (2015). Students' Conception on Heat and Temperature: A Study on Two Senior High Schools in the Central Region of Ghana, 4(4), 14.

Başer, M. (2006). Fostering Conceptual Change by Cognitive Conflict Based Instruction on Students' Understanding of Heat and Temperature Concepts. Eurasia Journal of Mathematics, Science and Technology Education, 2, 96114.

https://doi.org/10.12973/ejmste/754 58

Boa, E. A., Wattanatorn, A., \& Tagong, K. (2018). The development and validation of the Blended Socratic Method of Teaching (BSMT): An instructional model to enhance critical thinking skills of undergraduate business students. Kasetsart Journal of Social Sciences, $\quad 39(1), \quad 81-89$. https://doi.org/10.1016/j.kjss.2018. 01.001

Brookes, D. T., \& Etkina, E. (2015). The Importance of Language in Students' Reasoning About Heat in Thermodynamic Processes. International Journal of Science Education, 37, 759-779. 
The Students Misconception: The Developing of Socratic Dialogue Media

https://doi.org/10.1080/09500693.2 015.1025246

Creswell, J. W. (2013). Educational Research: Planning, Conducting, And Evaluating Qualitativ And Quantitative Research. Pearson Education, Inc. Retrieved from http://pearsonhighered.com

Kang, H., Scharmann, L. C., Kang, S., \& Noh, T. (2010). Cognitive conflict and situational interest as factors influencing conceptual change, 5(4), 383-405.

Leinonen, R., Asikainen, M. A., \& Hirvonen, P. E. (2013). Overcoming students' misconceptions concerning thermal physics with the aid of hints and peer interaction during a lecture course. Physical Review Special Topics - Physics Education Research, 9. https://doi.org/10.1103/physrevstpe r.9.020112

Marcisz, N. A., \& Woien, S. (2010). A Case Study: Enhancing Critical Thinking Skills in an Online Health Care Ethics Course, 6(2), 9.

Oyler, D. R., \& Romanelli, F. (2014). The Fact of IgnoranceRevisiting the Socratic Method as a Tool for Teaching Critical Thinking. American Journal of Pharmaceutical Education, 78(7), 144. https://doi.org/10.5688/ajpe787144

Pebriana, I. N. (2016). Pengembangan Media Dialog Sokratik Sebagai Alat Bantu Untuk Meningkatkan Pemahaman Konsep Kalor. Skripsi.

Prince, M., Vigeant, M., \& Nottis, K. (2012). Development of the Heat and Energy Concept Inventory:
Preliminary Results on the Prevalence and Persistence of Engineering Students' Misconceptions. Journal of Engineering Education, 101, 412438. https://doi.org/10.1002/j.21689830.2012.tb00056.x

Raymond A. Serway, \& Jewet Jr., J. W. (2014). Physics for Scientists and Engineers (9th ed.). United States of America: Physical Sciences: Mary Finch.

Sunardi, S., Retno P., P., \& Andreas B., D. (2016). Fisika untuk Siswa SMA/MA XI. Penerbit Yrama Widya. Retrieved from http://yrama-widya.co.id

Sutopo, \& Waldrip, B. (2014). Impact of A Representational Approach on Students' Reasoning And Conceptual Understanding in Learning Mechanics. International Journal of Science and Mathematics Education, 12(4), 741-765.

https://doi.org/10.1007/s10763-

013-9431-y

Varma, P., He, B., Iter, D., Xu, P., Yu, R., De Sa, C., \& Ré, C. (2016). Socratic Learning: Augmenting Generative Models to Incorporate Latent Subsets in Training Data. ArXiv:1610.08123 [Cs, Stat]. Retrieved from http://arxiv.org/abs/1610.08123 